\title{
O Dicastério para o Serviço do Desenvolvimento Humano Integral
}

The Dicastery for Promoting Integral Human Development

\section{Denilson Geraldo ${ }^{1}$}

O Papa Francisco constituiu no Vaticano em 2016 o Dicastério para o Serviço do Desenvolvimento Humano Integral ${ }^{2}$ que terá a missão de promover o desenvolvimento da pessoa à luz do Evangelho e, na esteira da doutrina social da Igreja mediante o cuidado da justiça, promover a cultura da paz e da proteção da criação. Esse novo dicastério atuará nas áreas relacionadas com as migrações, os necessitados, os enfermos, as vítimas dos conflitos armados e desastres naturais, os encarcerados, os desempregados e os que sofrem qualquer forma de escravidão e de tortura. Esse novo organismo recolherá informações e resultados de pesquisa sobre a justiça e a paz, o desenvolvimento dos povos, a promoção e proteção da dignidade humana e dos direitos humanos; avaliará esses dados e informará às Conferências Episcopais suas conclusões, oferecendo material de estudo e apoio às dioceses. $\mathrm{O}$ novo dicastério também poderá estabelecer relações com associações, instituições e organizações não governamentais, mesmo fora da Igreja Católica, comprometidas com a promoção da justiça e da paz, em diálogo com representantes de governos civis e outros sujeitos de direito internacional.

Interessante observar que o nome do novo organismo da Santa Sé tem a designação de Humanismo Integral. Essa expressão remonta a obra literária de Jacques Maritain (1882-1973), literato e filósofo francês que se converteu ao catolicismo em 1906, com sua esposa Ra-

\footnotetext{
1 Doutor em Direito Canônico pela Pontifícia Universidade Lateranense de Roma; Professor do Instituto Superior de Direito Canônico de Santa Catarina e do Instituto de Direito Canônico de Londrina. Diretor do Istituto San Vincenzo Pallotti (Roma). Email: denil.ge@gmail.com

2 www.humandevelopment.va
} 
íssa Maritain, influenciados por Léon Bloy. Para Jacques Maritain o verdadeiro humanismo manifesta a grandeza criacional da pessoa, na qual participa da natureza e da história, desenvolve as forças internas e transforma a realidade em caminhos para a liberdade. O Humanismo Integral de Maritain é cristão e concebe a ação humana motivada pela fé em diálogo com o mundo social e a criação.

$\mathrm{Na}$ Encíclica Caritas in veritate, o Papa Bento XVI considerou que o humanismo integral nessa mesma direção, levando a compreender que a adesão aos valores do cristianismo é um elemento útil e mesmo indispensável para a construção da sociedade (n. 4), pois a Igreja quando anuncia, celebra e atua na caridade, tende a promover o desenvolvimento integral do ser humano (n. 9). "O desenvolvimento autêntico deve ser integral, quer dizer, promover todos os homens e o homem todo" já afirmava Paulo VI na Populorum progressio (n. 14) e o Evangelho é fundamental ao desenvolvimento porque Jesus Cristo revela a pessoa a si mesmo (Gaudium et spes, n. 2), ou seja, ser cristão significa estar profundamente inserido na vida da sociedade. Portanto, a vocação cristã a tal desenvolvimento compreende tanto o plano natural como o plano sobrenatural, não sendo suficiente progredir apenas do ponto de vista econômico e tecnológico, mas é preciso que o desenvolvimento seja verdadeiro e integral, tanto sobre a vertente do ambiente como sobre a vertente da vida, da sexualidade, do matrimônio, da família, das relações sociais, etc (n. 51).

O Papa Francisco, por sua vez, na Encíclica Laudato Si constata que o crescimento nos últimos dois séculos não significou, em todos os seus aspectos, um verdadeiro progresso integral (n. 46). Francisco convida a participarmos de uma ecologia integral que conduz ao pleno desenvolvimento do gênero humano (n. 67). O mercado, por si mesmo, não garante o desenvolvimento humano integral nem a inclusão social (109), sendo indispensável para a ecologia integral incluir o valor do trabalho, tão sabiamente desenvolvido por São João Paulo II na sua Encíclica Laborem excercens. No mundo em que vivemos, não há duas crises, uma ambiental e outra social, como se estivessem separadas, mas uma única e complexa crise socioambiental. As diretrizes para a solução requerem uma abordagem integral para combater a pobreza, devolver a dignidade aos excluídos e, simultaneamente, 
cuidar da natureza (n. 139) em vista do bem comum que desempenha um papel central e unificador na ética social (n. 156). O bem comum pressupõe o respeito pela pessoa humana enquanto tal, com direitos fundamentais e inalienáveis orientados para o seu desenvolvimento integral (n. 157), direitos esses dos quais a família participa na formação integral, desenvolvendo a pessoa como um todo. Uma ecologia integral exige que se dedique algum tempo para recuperar a harmonia serena com a criação, refletir sobre o nosso estilo de vida e os nossos ideais, contemplar o Criador, que vive entre nós e se manifesta naquilo que nos rodeia (n. 225). Uma ecologia integral é feita também de simples gestos cotidianos, pelos quais quebramos a lógica da violência, da exploração, do egoísmo (n. 230).

Podemos chamar de humanismo integral ou ecologia integral, na verdade, o que importa é a visão de Igreja que o Papa Francisco deseja manifestar com esse novo Organismo da Santa Sé. O cristão está sim na sociedade, não é separado, participa de tudo, vive tudo, envolve-se em todos os ambientes e não se coloca acima de alguém, mas vive intensamente o cotidiano. É melhor correr o risco de se sujar com a realidade do que viver distanciado dela. Quanto mais entramos nos dramas sociais, mais entendemos que Deus se fez homem e veio nos trazer um humanismo ou uma ecologia integral. 